\title{
Nanotechnology for cancer treatment
}

\author{
William H. Gmeiner ${ }^{*}$ and Supratim Ghosh \\ Department of Cancer Biology, Wake Forest School of Medicine, Winston-Salem, NC 21757, \\ USA; and Program of Molecular Genetics, Wake Forest School of Medicine, Winston-Salem, NC \\ 21757, USA
}

\begin{abstract}
Nanotechnology has the potential to increase the selectivity and potency of chemical, physical, and biological approaches for eliciting cancer cell death while minimizing collateral toxicity to nonmalignant cells. Materials on the nanoscale are increasingly being targeted to cancer cells with great specificity through both active and passive targeting. In this review, we summarize recent literature that has broken new ground in the use of nanotechnology for cancer treatment with an emphasis on targeted drug delivery.
\end{abstract}

\section{Keywords}

cancer; drug-delivery; nanotechnology

\section{Introduction}

The need for an advanced technology to play an important role for cancer treatment is clearly evident in the statistics indicating that cancer incidence, prevalence, and mortality remain at exceedingly high levels [1]. Cancer is one of the leading causes of deaths worldwide with an estimated 7.6 million individuals lost each year and accounting for 13\% of all deaths. Cancer-related mortality is expected to rise to 13.1 million by 2030. Cancer is not a single disease but a multitude of diseases with each organ or system developing a distinct set of diseases. Many instances of cancer could be avoided, with some estimates indicating that about $30 \%$ of cancer deaths are associated with smoking or other lifestyle factors or dietary practices that could potentially be avoided by changes in human behavior [2-4]. Nonetheless, the majority of cancers cannot be avoided by simple behavioral changes and require technological innovation to improve outcomes. The developed world has had notable success in limiting cancer caused by viral infections [e.g., human papilloma virus (HPV)] [5-7]. This success could be further enhanced by more widespread implementation of existing vaccine technologies and also by using nanotechnology as well as other technologies to improve vaccination efficiency [5-8]. Nanotechnology may also be able to increase the percentage of cancers that are diagnosed early through improved imaging and this, in conjunction with more aggressive implementation of existing screening technologies, will lead to improved outcomes for cancer patients $[9,10]$. Still, for many cancer types, new

*Corresponding author: William H. Gmeiner, Department of Cancer Biology, Wake Forest School of Medicine, Winston-Salem, NC 21757, USA, bgmeiner@wakehealth.edu. 
approaches for treating established disease are required. To address these therapeutic requirements, nano-sized molecular tools capable of distinguishing between malignant and nonmalignant cells as well as delivering a lethal payload should be developed. This review summarizes several of the most innovative technologies that have been reported in recent years and that hold promise for improving outcomes for cancer patients.

\section{Tumor targeting}

One of the potential fundamental advantages of nanotechnology for cancer treatment is tumor targeting (Figure 1). The ability to differentiate malignant cells from nonmalignant and to selectively eradicate malignant cells is central to the mission of nanotechnology as it relates to cancer treatment. Two fundamental processes are involved in differentiating malignant and nonmalignant cells: passive and active targeting. Passive targeting takes advantage of the enhanced permeability and retention (EPR) effect $[11,12]$ to increase the concentration of nanoparticles (NPs) in the tumor. Active targeting [13] may involve selective molecular recognition of antigens, frequently proteins, that are expressed on the surfaces of cancer cells in order to localize NPs to malignant cells or, alternatively, exploits biochemical properties associated with malignancy such as matrix metalloproteinase secretion [14]. Passive and active targeting may be deployed independently, or the two approaches may be combined. Both strategies benefit from surface modifications of NPs that minimize uptake by the macrophage phagocytic system (MPS) [15], thus, maximizing time in circulation.

\subsection{Passive targeting via the EPR}

It is well known that the tumor vasculature is leaky relative to the hierarchical structure of normal vasculature, in part, because malignant cells are not responsive to cell signaling required for orderly vasculogenesis $[16,17]$. Macromolecules may enter the tumor through leaky vasculature and persist, in part, because of reduced lymph clearance [18] in tumors by a phenomenon referred to as the enhanced permeability and retention effect (EPR) [19]. The efficiency of the EPR depends on tumor size, tumor type, and tumor heterogeneity, among other factors. The efficiency of the EPR is also critically dependent on the size of the therapeutic being targeted. As described by Maeda, localization of substances via the EPR is functionally operational over the MW range $40 \mathrm{kDa}-800 \mathrm{kDa}$, which for globular proteins corresponds to minimal radii from 2.3 to $6.1 \mathrm{~nm}$ [20]. The preferred dimensions for the localization of proteins in tumor tissue via the EPR surprisingly revealed a minimum at 25 $\mathrm{kDa}$ with enhanced uptake for proteins larger or smaller - although smaller peptides required active targeting for retention. In contrast, liposomes did not benefit from active targeting [20, 21]. A variety of NPs have been shown to localize in tumor tissue via the EPR including multiwalled carbon nanotube (MWNT), single-walled carbon nanotube (SWNT) [22, 23], and liposomes [24], as well as viral NPs [25]. NPs may differ considerably in density, and other features from globular proteins and NPs several hundred nanometers in a single dimension have been reported to localize to tumor tissue via the EPR. To our knowledge, the relative efficiency of tumor localization via the EPR for various NPs has not been systematically investigated in any tumor model. An interesting variant of passive targeting via the EPR was recently described in which gold nanorods were delivered to 
tumor tissue via the EPR and used to heat the tumor upon laser irradiation. The procedure was followed by delivery of the anticancer agent ADHGM to cancer cells through recognition of GRP78 that was upregulated on prostate cancer cells in response to the increased temperature [26].

\subsection{Active targeting}

In principle, any ligand that displays preferential binding toward malignant relative to nonmalignant cells or that results in selective activation proximal to malignant cells $[27,28]$ can be used to actively target malignant cells. In this regard, growth factor receptors such as epidermal growth factor receptor (EGFR) [29], transferrin [30-33], death receptor (DR) complexes (e.g., DR5 [34, 35]), and folate ligand [36-40] as well as tumor-specific antigens (e.g., PSMA [41, 42]) have all been utilized to localize NPs to malignant cells via active targeting. A variety of chemical and biological molecules have been used to direct NPs to malignant cells expressing the molecular target receptor including monoclonal antibodies [43], small molecules, and nucleic acid aptamers [44, 45]. Factors that contribute to one type of targeting molecule being preferentially utilized include molecular weight (MW), targeting affinity, valency, and biocompatibility. Although active targeting is conceptually straightforward, this type of targeting does not uniformly enhance tumor localization. For example, monoclonal antibody (mAb) targeting was found in some instances not to enhance tumor localization [46]. Further, active targeting may impact other variables, such as time in circulation, and these indirect effects may confound the effects of direct targeting. Using variable amounts of targeting ligand, it was shown that active targeting of NPs affects cellular uptake within a tumor, but not the targeting to the tumor itself [30]. Thus, active targeting remains an important strategy for NP localization; however, caution must be exercised in attributing the biological effects observed to active targeting.

\subsection{Minimizing MPS uptake}

The accumulation of NPs in tumor tissues requires prolonged time in circulation and avoidance of clearance through uptake by the reticuloendothelial system (RES) (a.k.a. MPS [47]). Coating of NPs with polyethylene glycol (PEG) or other amphipathic agents reduces the affinity of proteins involved in the opsonization of NPs and, thus, reduces MPS uptake [48]. PEGylation reduced MPS uptake of quantum dots (QDs) up to ninefold, while peptide derivatization had a lesser effect [49]. Dai and coworkers showed that using $90 \mathrm{kDa}$ amphiphilic poly(maleic anhydride-alt-1-octadecene)-methoxy poly(ethylene glycol) [C18PMH-mPEG], they were able to get $30 \%$ of the administered dose of modified SWNT localized in tumor tissue [22, 23]. A recent study evaluated the effects of surface modification of gold nanoparticles (GNPs) on the interaction with blood components including NP biodistribution [50]. GNPs are internalized by monocytes regardless of surface modification. Enhanced tumor accumulation correlated with enhanced circulation and was found to be surface-dependent with fresh, rather than lyophilized PEG, enhancing time in circulation. The effects of surface charge on cell uptake and biodistribution of PEGoligocholic acid micelles were systematically evaluated [51]. A slight negative charge was found to maximize tumor uptake and minimize uptake by MPS cells of the liver. Surface modification to reduce MPS uptake continues to be an important strategy for developing NPs with improved therapeutic activity. For example, low MW chitosan has been developed 
as an alternative to PEGylation that may allow for retention of specific molecular interactions that are masked by PEG [52].

\section{NP-mediated cancer imaging}

NPs may be highly useful for imaging applications [53] because of the high surface area-tovolume ratio (relative to larger particles) as well as having the potential for numerous sites for chemical modification that may be used to amplify imaging sensitivity [53]. While the avoidance of macrophage uptake is important for NP-mediated effects in many instances, the propensity of NPs to undergo macrophage-mediated phagocytosis may be beneficial for imaging applications. Superparamagnetic iron oxide NPs (IONPs) have been used for MR imaging of lymph nodes following macrophage uptake, which may be beneficial for detecting metastatic disease $[54,55]$. The poor lymphatic drainage of tumors that contributes to accumulation of NPs for drug-delivery applications may also be used to image tumors with IONPs [56]. IONPs have also been conjugated to the amino-terminal fragment of urokinase plasminogen activator to specifically image breast cancer [57], while conjugation with an antibody to EGFR was used for imaging brain tumors [58]. Generalized chemical methods for developing surface-modified IONP for cancer imaging are being developed [59]. Recently, a new approach for in vivo assembly of NPs with imaging agents was described [60].

Several different types of NP have been conjugated with chelates of paramagnetic $\mathrm{Gd}^{3+}$ to enhance MR contrast including dendrimers, micelles, and cNTs [61]. In principle, highly specific imaging of small numbers of malignant cells could be achieved by conjugating a targeting agent, such as a mAb, with $\mathrm{Gd}^{3+}$-chelates to affect MR relaxivity or conjugating with other imaging probes. In practice, sensitivity is a problematic issue of imaging research. One potential approach is to amplify the signal in the area of interest by delivering a suitable enzyme. For example, horseradish peroxidase has been delivered to xenograft tumors via conjugation to a tumor-specific mAb, and this has been used to oligomerize MRspecific ligands to achieve an enhanced signal for tumor detection and imaging [62]. GNPs have also been used for enhancing contrast in X-ray images providing advantages relative to triiodobenzene [63]. In addition to enhancing contrast for improved imaging, GNPs affect $\mathrm{X}$-ray scatter and can be used to localize radiation and improve treatment outcomes $[64,65]$.

In principle, NPs can be used for both imaging and treatment applications [66]. For example, $\mathrm{TiO}_{2}$ NPs may be used both to enhance CT (computed tomography) image contrast and as sensitizers for photodynamic therapy [67]. Magnetic NPs can be used for both improved MR imaging and hyperthermia applications for advanced cancer treatment [68]. The $\alpha_{v} \beta_{3}$ integrin-specific peptide motif RGD may be used to direct IONPs to malignant cells for both enhancing contrast as well as hyperthermia-based therapy [69]. IONPs can be conjugated with methotrexate [70], paclitaxel (PTX) [71], or other anticancer drugs [72] for theranostic (therapeutic+diagnostic) applications. Gold NPs, quantum dots, and cNTs have also been modified and utilized for potential theranostic applications [69]. 


\section{NP-mediated cancer treatment}

NPs that are being used for, or developed for, cancer treatment are generally not inherently cytotoxic. Thus, NPs must alter the chemical and/or physical environment specifically in the region proximal to the cancer cell in order to exert cytotoxicity. As mentioned in the preceding sections, NPs are targeted to malignant cells specifically via passive targeting via the EPR and/or active targeting, frequently based upon specific molecular recognition events such as EGF/EGFR interactions. Once localized to the tumor, NPs evoke a cytotoxic response in cancer cells generally using one of three modalities: (1) drug release [73], (2) hyperthermia or thermal ablation [74], and (3) reactive oxygen species (ROS)-mediated killing [75]. These modalities can be applied independently or may be utilized together in a multimodality approach for cancer treatment. The advantages relative to non-NP-mediated approaches for ablation are that NPs may mediate extremely localized effects that are based on molecular recognition events at a cellular level. Thus, by directing NPs to specific cells (e.g., malignant cells), one can enhance eradication of neoplastic tissue while limiting damage to proximal or even adjacent normal cells. This sort of approach is particularly valuable for highly infiltrative malignancies, such as glioblastoma multiforme (GBM), where malignant cells cannot be positionally distinguished from nonmalignant cells.

\subsection{NP-mediated drug release}

NP-mediated drug delivery is based upon the premise that it is, for the most part, no more difficult to kill a cancer cell than any other nonmalignant cells. Conventional cytotoxic agents, such as doxorubicin (DOX), are highly cytotoxic to cancer cells but are, unfortunately, highly cytotoxic to nonmalignant cells as well - particularly rapidly dividing cells in the gastrointestinal tract and bone marrow. NP-mediated delivery of conventional cytotoxic drugs allows for control over drug cytotoxicity based upon the biodistribution profile for the NP rather than for the free drug [76, 77]. NP-mediated drug delivery also reduces the excretion rate for low MW cytotoxic drugs providing an increased opportunity to remain in the circulation and accumulate in the targeted region. A successful example of nanotechnology-mediated drug delivery is the liposome-mediated delivery of DOX (e.g., Doxil) [78] that has substantially reduced cardiotoxicity [79] relative to free DOX. The albumin-conjugated PTX NP (Abraxane) demonstrated promising efficacy in breast cancer as well as ovarian cancer and is approved by the FDA [80, 81]. The platform of nanotechnology addressed the hydrophobicity-related issue of PTX and helped to prepare a toxic solvent (cremphor)-free formulation reducing the overall toxicity of the therapeutic [80]. A number of recent studies have also proposed novel approaches for improved drugdelivery using NPs. Our laboratory has shown that creating a nano-sized DNA polymer results in enhanced antileukemic activity relative to low MW drugs [82].

\subsection{Controlling NP-mediated drug release}

The use of NPs for drug delivery requires release of drug at the tumor site or into malignant cells upon internalization. Thus, strategies to enhance drug release at the tumor site are an important component of NP design strategies for theranostic applications. One of the potential problems with current drug delivery methods is that drug is only slowly released from the NP following localization to tumor tissue via the EPR. This slow release may result 
in lower free-drug levels that are insufficient to exert a biological, e.g., cytotoxic response [73]. Thermally labile liposomes were developed that expedite drug delivery following tumor localization via the EPR, a strategy that is moving forward into clinical trials [73].

\subsection{Clinical candidates for NP-mediated drug delivery}

The fundamental features important for successful implementation of NPs as therapeutic agents including passive and active targeting and MPS avoidance have been developed to the extent that NP-based therapeutic candidates beyond liposomes are entering clinical trials and displaying drug release and toxicity profiles demonstrating significant improvements relative to conventional chemotherapy. A particular instance of a NP that combines passive targeting via the EPR with active targeting as well as with evasion of immune cells is BIND-014, which recently entered clinical trials [41]. BIND-014 uses the RNA aptamer A10-03 to localize the NP to prostate cancer cells and releases docetaxel chemotherapy. PEG is used to minimize the uptake of NP by the MPS. Besides use of NP for drug delivery, imaging-based NPs are also entering clinical trials such as [ $\left.{ }^{18} \mathrm{~F}\right]$-FAC family of PETimaging agents that are being tested for estimation of chemotherapies such as gemcitabine, cytarabine, and fludarabine uptake $[83,84]$. Another significantly promising example are NPs containing magnetic resonance imaging (MRI) contrast agents targeted to the $\alpha_{v} \beta_{3^{-}}$ intregrin found on the surface of the newly developing blood vessels associated with early tumor development $[85,86]$. A viral nanoparticle (VPN) has been developed for gene therapy against leukemia [87]. Cyclodextrin-based NP that safely encapsulates a smallinterfering RNA (siRNA) agent capable of shutting down a key enzyme in cancer cells is also under clinical trials [88-90]. Cyclodextrin-conjugated camptothecin polymeric NP is in currently under clinical trial [91]. In a collaborative study between Harvard Medical School and MIT, a clinical study is under process to determine the potential of a novel class of superparamagnetic NPs to identify circulating premetastatic cells [92].

\subsection{Thermal ablative approaches to cancer treatment}

Locally ablative approaches [93] including radiofrequency ablation (RFA) [94, 95], laserinduced thermotherapy (LITT) [96], and microwave ablation [97] are widely used for treatment of metastatic disease [98], chiefly to the lung [99] and liver [100] that originate from diverse primary tumors. These currently implemented thermal ablative approaches do not utilize NPs, and thus, implementation is based on macroscopic detection of metastatic lesions rather than on specific molecular recognition as is becoming increasingly possible using NP-mediated ablative approaches. Radiologic guidance can improve tumor specificity $[101,102]$ increasing the efficacy of cancer therapy. It is important to note that micrometastatic disease, particularly at sites distant from the primary tumor, is an extremely poor prognostic indicator (Figure 2). Thus, the application of nanotechnology approaches for eradicating micrometastatic disease represents one of the most important objectives for using nanotechnology for cancer treatment. Although not yet specific on a molecular level, current thermal-ablative approaches do have a high demonstrated success rate with up to 97\% positive response using RFA and 98\% using LITT for treatment of breast metastases [103] and colorectal cancer metastases [104]. Cryoablation alternatively uses localized low temperatures to freeze and kill neoplastic tissue [105]. Our laboratory demonstrated that DNA-encased MWNTs had the capacity to thermally eradicate prostate cancer xenografts 
[74] in nude mice model upon near-infrared(NIR) radiation, without causing significant damage to the adjacent tissue. DNA enhanced the dispersion of the MWNTs, which as with other NTs, are excited by tissue-penetrating NIR radiation. The use of double-strand DNA (dsDNA)-complexed SWNTs with conjugation to a mAb for selective delivery and localized thermal ablation was recently described $[106,107]$ as potential cancer therapeutics. Focal ablative therapy is being explored as an alternative to surgery and radiation therapy for the treatment of localized prostate cancer [108]. It is important to note that in addition to any direct thermal ablative effect mediated by NPs, ablative therapies also modulate the immune response, and this will affect the overall antitumor response [109].

\subsection{Nanotechnology and photodynamic therapy}

The cytotoxic effects of photosensitizing porphyrins in conjunction with light exposure are well documented, and photodynamic therapy (PDT) is widely used for treating bladder cancer [110], esophageal cancer [111], as well as for other malignancies and other neoplastic conditions such as macular degeneration [112]. NP-mediated delivery of photosensitizing porphyrins [113] would be expected to confer several of the same advantages that are associated with NP-mediated delivery of cytotoxic drugs including increased local intratumoral concentrations resulting from the enhanced permeability and retention (EPR) effect [12] and reduced systemic toxicities and, in the case of photoactive compounds, reduced light sensitivity [114]. Alternatively, locally administered NPs composed, in part, of photosensitizing porphyrins would be expected to be retained in the targeted tissue allowing multiple exposures to light with a single administered dose.

\subsection{Nanoparticle-mediated gene therapy}

Although it has been known for decades that DNA is the molecular basis of life that carries information from generation to generation, until nanotechnology started using DNA for the detection of macromolecules or to produce biochips, other potentials of this biomolecule has not been realized. The cellular role of DNA is relatively limited, perhaps, because of the restrictions imposed by structure and bonding between complementary strands. Apart from these cellular roles, nanotechnology is now discovering many more hidden potentials of DNA. By exploiting its amphipathic property, single-stranded DNA (ssDNA) sequences could be used to solubilize hydrophobic NPs like carbon nanotubes (cNTs) to make it suitable for in vivo use. DNA sequences have the ability to process information in biochemical assays. Its structure and self-assembling property made it an ideal scaffolding material to arrange NPs in biochip and biosensor production.

Antisense gene therapy is a potentially powerful tool for both biomedical researches as well as for clinical treatments of various ailments, including cancer. Although the potential of antisense gene therapy was recognized decades ago, their development into viable therapeutics has faced challenges with regard to low transfection efficiency, DNAse degradation, entry into diverse cell types, and toxicity of the transfecting agents. In the last few years, several researchers demonstrated the potential of augmenting gene therapy with the help of nanotechnology $[87,88,90,115,116]$ addressing a majority of these issues and successfully translated into clinical trials. 


\subsection{Multimodality NPs for cancer treatment}

Tumors are heterogeneous in nature, consisting of multiple cell types and with complex interplay between the cellular components contributing to make treatment challenging. One of the potential advantages of nanotechnology is the capacity to deliver and/or utilize more than a single therapeutic modality for treatment. Our laboratory is investigating a novel multimodality NP that displayed strong antitumor activity through light-mediated ROS generation with release of DNA (Ghosh et al., in preparation). An example of a nanomaterial that had been used for multimodality applications, including drug-delivery and thermal ablation, are cNTs [117]. Heat alone is unlikely to be an ideal modality for inducing tumor cell death as heat can be dissipated by blood vessels. Heat can also enhance chemotherapeutic efficacy (hyperthermia), and heat-mediated chemotherapy release may augment or enhance direct thermal ablation. Nutritional deprivation, hypoxia, and acidic $\mathrm{pH}$ have all been demonstrated to sensitize tumor cells to hyperthermia $[118,119]$.

Chemosensitization resulting from hyperthermia can enhance therapeutic efficacy of chemotherapy, and multi-modality NPs can be used for both drug delivery as well as stimulation of hyperthermia. A portion of the hormone FGF was used to direct gold NPs to U2OS cancer cells that had been transfected with the fibroblast growth factor receptor (FGFR), and it was demonstrated that cell death could be induced upon exposure to NIR irradiation [120]. Gold nanospheres were recently loaded with DOX and targeted to EphB4expressing tumors using a peptide identified using phage display [121]. Hyperthermia was stimulated by NIR irradiation; however, other approaches including use of alternating magnetic fields in conjunction with IONPs [122] are being evaluated in preclinical as well as clinical studies, and the use of high-intensity focused ultrasound (HIFU) for hyperthermia in conjunction with thermo-sensitive liposomes (TSL) was recently described [123]. Temperature-triggered release of the drug from liposomes is expected to enhance local drug concentrations in the tumor-enhancing treatment efficacy without increasing systemic toxicity. While temperatures above $42^{\circ} \mathrm{C}$ may shut down blood flow, temperatures in the $41-42^{\circ} \mathrm{C}$ range can markedly enhance the effects of chemo therapy and radiation treatment. For example, approximately $30 \%$ less radiation is required to kill cells heated to $42^{\circ} \mathrm{C}$ relative to physiological temperature [124], although it is technically difficult to maintain tissue temperatures in a controlled fashion above physiological temperature. MR is valuable in temperature mapping, and MR-HIFU systems can be used to locally control temperatures.

\section{NP-related toxicity}

One of the potential risks of using nanomaterials for cancer therapy as well as for human health, in general, is the potential for toxicity $[68,75,125]$. Nanomaterials are diverse in chemical composition, charge, and even to some degree size, and thus, general statements concerning toxicity are likely not possible. Some of the major concerns are that NPs may be carcinogenic by, for example, causing increased ROS production and leading to DNA mutations. NP exposure is also associated with asthma, bronchitis, Alzheimer's disease, and Parkinson's disease. A variety of vascular-related events such as blood clots are associated with NPs that enter the circulatory system. Further research is required to delineate real risks 
associated with NP use and determining to what extent potential benefits outweigh these risks.

\section{Summary and future perspective}

Nanotechnology is playing an increasingly important role in cancer diagnosis and treatment. The size regime of NPs is small compared to cells and cellular organelles permitting NPs to interact with specific features of cells and allowing for tumor cell localization through active targeting $[76,126]$. The size regime of NPs is also appropriate for passive targeting to tumor tissue via the EPR [77]. Thus, nano-sized materials have particular advantages for cancer treatment with distinct features relative to low molecular weight drugs. These properties are being effectively exploited for improved delivery of chemotherapeutic drugs [78] resulting in both enhanced anticancer activity and reduced systemic toxicity.

The chemical diversity of NPs allows for interactions with magnetic fields [127], NIR irradiation [128], and other external fields to provide a conduit for highly specific interactions between external fields with tumor tissue and potentially with individual malignant cells in vivo. The diverse material composition of NPs also permits perturbation of external fields providing enhanced contrast for imaging applications [129]. The unparalleled specificity of coupling between external fields and malignant cells in the context of normal tissue provided by appropriate NPs is expected to lead to more accurate and earlier diagnoses and improved treatment outcomes. One concern potentially limiting the applicability of some NPs for cancer treatment is the toxicity [79] of nanomaterials that requires further investigation. Nonetheless, improved cancer treatments using nanotechnology will continue to be developed and result in improved treatment outcomes.

\section{Acknowledgments}

This work was supported by DOD PCRP 093606 (WHG) and NIH-NCI P30CA012197 (WHG).

Abbreviations
$\begin{array}{ll}\text { cNT } & \text { carbon nanotube } \\ \text { CT } & \text { computed tomography } \\ \text { DOX } & \text { doxorubicin } \\ \text { DR } & \text { death receptor } \\ \text { dsDNA } & \text { double-strand DNA } \\ \text { EGFR } & \text { epidermal growth factor receptor } \\ \text { EPR } & \text { enhanced permeability and retention effect } \\ \text { FGFR } & \text { fibroblast growth factor receptor } \\ \text { GBM } & \text { glioblastoma multiforme } \\ \text { GNP } & \text { gold nanoparticle }\end{array}$




$\begin{array}{ll}\text { HIFU } & \text { high-intensity focused ultrasound } \\ \text { HPV } & \text { human papilloma virus } \\ \text { IONP } & \text { iron oxide nanoparticle } \\ \text { i.v. } & \text { intravenous } \\ \text { LITT } & \text { laser-induced thermo-therapy } \\ \text { mAb } & \text { monoclonal antibody } \\ \text { MPS } & \text { macrophage phagocytic system } \\ \text { MR } & \text { magnetic resonance } \\ \text { MW } & \text { molecular weight } \\ \text { MWNT } & \text { multi-walled carbon nanotube } \\ \text { NIR } & \text { near infrared } \\ \text { NP } & \text { nanoparticle } \\ \text { PEG } & \text { polyethylene glycol } \\ \text { PL } & \text { phospholipid } \\ \text { PTX } & \text { paclitaxel } \\ \text { RES } & \text { reticuloendothelial system } \\ \text { RF } & \text { radiofrequency } \\ \text { RFA } & \text { radiofrequency ablation } \\ \text { ROS } & \text { reactive oxygen species } \\ \text { sDDNA } & \text { single-stranded DNA } \\ \text { SWNT } & \text { single-walled carbon nanotube } \\ \text { TSL } & \text { thermosensitive liposome } \\ & \end{array}$

\section{References}

1. Ferlay J, Shin HR, Bray F, Forman D, Mathers C, Parkin DM. Estimates of worldwide burden of cancer in 2008: GLOBOCAN 2008. Int. J. Cancer. 2010; 127:2893-2917. [PubMed: 21351269]

2. Barnard RJ. Prevention of cancer through lifestyle changes. Evid. Based Complementary Altern. Med. 2004; 1:233-239.

3. Holmes RS, Vaughan TL. Epidemiology and pathogenesis of esophageal cancer. Semin. Radiat. Oncol. 2007; 17:2-9. [PubMed: 17185192]

4. Watabe K, Nishi M, Miyake H, Hirata K. Lifestyle and gastric cancer: a case-control study. Oncol. Rep. 1998; 5:1191-1194. [PubMed: 9683833]

5. Moniz M, Ling M, Hung CF, Wu TC. HPV DNA vaccines. Front. Biosci. 2003; 8:d55-d68. [PubMed: 12456324]

6. Parkin DM, Bray F. Chapter 2: The burden of HPV-related cancers. Vaccine. 2006; 24(Suppl 3) S3/11-25. 
7. Walboomers JM, Jacobs MV, Manos MM, Bosch FX, Kummer JA, Shah KV, Snijders PJ, Peto J, Meijer CJ, Munoz N. Human papillomavirus is a necessary cause of invasive cervical cancer worldwide. J. Pathol. 1999; 189:12-19. [PubMed: 10451482]

8. Paavonen J, Naud P, Salmeron J, Wheeler CM, Chow SN, Apter D, Kitchener H, Castellsague X, Teixeira JC, Skinner SR, Hedrick J, Jaisamrarn U, Limson G, Garland S, Szarewski A, Romanowski B, Aoki FY, Schwarz TF, Poppe WA, Bosch FX, Jenkins D, Hardt K, Zahaf T, Descamps D, Struyf F, Lehtinen M, Dubin G. Efficacy of human papillomavirus (HPV)-16/18 AS04-adjuvanted vaccine against cervical infection and precancer caused by oncogenic HPV types (PATRICIA): final analysis of a double-blind, randomised study in young women. Lancet. 2009; 374:301-314. [PubMed: 19586656]

9. Nystrom L, Rutqvist LE, Wall S, Lindgren A, Lindqvist M, Ryden S, Andersson I, Bjurstam N, Fagerberg G, Frisell J, Tabar L, Larsson L-G. Breast cancer screening with mammography: overview of Swedish randomised trials. Lancet. 1993; 341:973-978. [PubMed: 8096941]

10. Winawer S, Fletcher R, Rex D, Bond J, Burt R, Ferrucci J, Ganiats T, Levin T, Woolf S, Johnson D, Kirk L, Litin S, Simmang C. Colorectal cancer screening and surveillance: clinical guidelines and rationale-Update based on new evidence. Gastroenterology. 2003; 124:544-560. [PubMed: 12557158]

11. Maeda $H$. The enhanced permeability and retention (EPR) effect in tumor vasculature: the key role of tumor-selective macromo-lecular drug targeting. Adv. Enzyme Regul. 2001; 41:189-207. [PubMed: 11384745]

12. Maeda H. Macromolecular therapeutics in cancer treatment: the EPR effect and beyond. J. Control. Release. 2012; 164:138-144. [PubMed: 22595146]

13. Byrne JD, Betancourt T, Brannon-Peppas L. Active targeting schemes for nanoparticle systems in cancer therapeutics. Adv. Drug Deliv. Rev. 2008; 60:1615-1626. [PubMed: 18840489]

14. Hongmei, Li SSY.; Miteva, M.; Nelson, CE.; Werfel, T.; Giorgio, TD.; Duvall, CL. Matrix metalloproteinase responsive, proximity-activated polymeric nanoparticles for siRNA delivery. Adv. Funct. Mater. 2013; 23:3040-3052. [PubMed: 25214828]

15. Nie S. Understanding and overcoming major barriers in cancer nanomedicine. Nanomedicine (Lond). 2010; 5:523-528. [PubMed: 20528447]

16. Shchors K, Evan G. Tumor angiogenesis: cause or consequence of cancer? Cancer Res. 2007; 67:7059-7061. [PubMed: 17671171]

17. Weis SM, Cheresh DA. Tumor angiogenesis: molecular pathways and therapeutic targets. Nat. Med. 2011; 17:1359-1370. [PubMed: 22064426]

18. Yu MK, Park J, Jon S. Targeting strategies for multifunctional nanoparticles in cancer imaging and therapy. Theranostics. 2012; 2:3-44. [PubMed: 22272217]

19. Maeda H. Tumor-selective delivery of macromolecular drugs via the EPR effect: background and future prospects. Bioconjug. Chem. 2010; 21:797-802. [PubMed: 20397686]

20. Schmidt MM, Wittrup KD. A modeling analysis of the effects of molecular size and binding affinity on tumor targeting. Mol. Cancer Ther. 2009; 8:2861-2871. [PubMed: 19825804]

21. Wittrup KD, Thurber GM, Schmidt MM, Rhoden JJ. Practical theoretic guidance for the design of tumor-targeting agents. Method Enzymol: Protein Engineering for Therapeutics Vol203, Pt B. 2012; 503:255-268.

22. Liu Z, Chen K, Davis C, Sherlock S, Cao Q, Chen X, Dai H. Drug delivery with carbon nanotubes for in vivo cancer treatment. Cancer Res. 2008; 68:6652-6660. [PubMed: 18701489]

23. Robinson JT, Hong G, Liang Y, Zhang B, Yaghi OK, Dai H. In vivo fluorescence imaging in the second near-infrared window with long circulating carbon nanotubes capable of ultrahigh tumor uptake. J. Am. Chem. Soc. 2012; 134:10664-10669. [PubMed: 22667448]

24. Maruyama K. Intracellular targeting delivery of liposomal drugs to solid tumors based on EPR effects. Adv. Drug Deliv. Rev. 2011; 63:161-169. [PubMed: 20869415]

25. Wen AM, Shukla S, Saxena P, Aljabali AA, Yildiz I, Dey S, Mealy JE, Yang AC, Evans DJ, Lomonossoff GP, Steinmetz NF. Interior engineering of a viral nanoparticle and its tumor homing properties. Biomacromolecules. 2012; 13:3990-4001. [PubMed: 23121655] 
26. Gormley AJ, Larson N, Sadekar S, Robinson R, Ray A, Ghandehari H. Guided delivery of polymer therapeutics using plasmonic photothermal therapy. Nano Today. 2012; 7:158-167. [PubMed: 22737178]

27. Danhier F, Feron O, Preat V. To exploit the tumor microenvironment: passive and active tumor targeting of nanocarriers for anti-cancer drug delivery. J. Control. Release. 2010; 148:135-146. [PubMed: 20797419]

28. Mail JL, Raki M, Bergström KA, Uutela P, Lehtinen K, Hiltunen A, Pikkarainen J, Liang H, Pitkänen S, Määttä A-M, Ketola RA, Yliperttula M, Wirth T, Urtti A. Pre-targeting and direct immunotargeting of liposomal drug carriers to ovarian carcinoma. PLoS One. 2012; 7:e41410. [PubMed: 22844475]

29. Yang L, Mao H, Wang YA, Cao Z, Peng X, Wang X, Duan H, Ni C, Yuan Q, Adams G, Smith MQ, Wood WC, Gao X, Nie S. Single chain epidermal growth factor receptor antibody conjugated nanoparticles for in vivo tumor targeting and imaging. Small. 2009; 5:235-243. [PubMed: 19089838]

30. Choi CH, Alabi CA, Webster P, Davis ME. Mechanism of active targeting in solid tumors with transferrin-containing gold nanoparticles. Proc. Natl. Acad. Sci. USA. 2010; 107:1235-1240. [PubMed: 20080552]

31. Huang RK, Steinmetz NF, Fu CY, Manchester M, Johnson JE. Transferrin-mediated targeting of bacteriophage HK97 nanoparticles into tumor cells. Nanomedicine (Lond.). 2011; 6:55-68. [PubMed: 21182418]

32. Ishida O, Maruyama K. Transferrin conjugated PEG-liposomes as intracellular targeting carrier for tumor therapy. Nihon Rinsho. 1998; 56:657-662. [PubMed: 9549352]

33. Li JL, Wang L, Liu XY, Zhang ZP, Guo HC, Liu WM, Tang SH. In vitro cancer cell imaging and therapy using transferrin-conjugated gold nanoparticles. Cancer Lett. 2009; 274:319-326. [PubMed: 18977071]

34. Fay F, McLaughlin KM, Small DM, Fennell DA, Johnston PG, Longley DB, Scott CJ. Conatumumab (AMG 655) coated nanoparticles for targeted pro-apoptotic drug delivery. Biomaterials. 2011; 32:8645-8653. [PubMed: 21875750]

35. Ding B, Wu X, Fan W, Wu Z, Gao J, Zhang W, Ma L, Xiang W, Zhu Q, Liu J, Ding X, Gao S. Anti-DR5 monoclonal antibody-mediated DTIC-loaded nanoparticles combining chemotherapy and immunotherapy for malignant melanoma: target formulation development and in vitro anticancer activity. Int. J. Nanomed. 2011; 6:1991-2005.

36. Dixit V, Van den Bossche J, Sherman DM, Thompson DH, Andres RP. Synthesis and grafting of thioctic acid-PEG-folate conjugates onto Au nanoparticles for selective targeting of folate receptor-positive tumor cells. Bioconjug. Chem. 2006; 17:603-609. [PubMed: 16704197]

37. Esmaeili F, Ghahremani MH, Ostad SN, Atyabi F, Seyedabadi M, Malekshahi MR, Amini M, Dinarvand R. Folate-receptor-targeted delivery of docetaxel nanoparticles prepared by PLGAPEG-folate conjugate. J. Drug Target. 2008; 16:415-423. [PubMed: 18569286]

38. Kularatne SA, Low PS. Targeting of nanoparticles: folate receptor. Methods Mol. Biol. 2010; 624:249-265. [PubMed: 20217601]

39. Schroeder JE, Shweky I, Shmeeda H, Banin U, Gabizon A. Folate-mediated tumor cell uptake of quantum dots entrapped in lipid nanoparticles. J. Control. Release. 2007; 124:28-34. [PubMed: 17928088]

40. Song EQ, Zhang ZL, Luo QY, Lu W, Shi YB, Pang DW. Tumor cell targeting using folateconjugated fluorescent quantum dots and receptor-mediated endocytosis. Clin. Chem. 2009; 55:955-963. [PubMed: 19282359]

41. Hrkach J, Von Hoff D, Mukkaram Ali M, Andrianova E, Auer J, Campbell T, De Witt D, Figa M, Figueiredo M, Horhota A, Low S, McDonnell K, Peeke E, Retnarajan B, Sabnis A, Schnipper E, Song JJ, Song YH, Summa J, Tompsett D, Troiano G, Van Geen Hoven T, Wright J, LoRusso P, Kantoff PW, Bander NH, Sweeney C, Farokhzad OC, Langer R, Zale S. Preclinical development and clinical translation of a PSMA-targeted docetaxel nanoparticle with a differentiated pharmacological profile. Sci. Transl. Med. 2012; 4 128ra39. 
42. Kasten BB, Liu T, Nedrow-Byers JR, Benny PD, Berkman CE. Targeting prostate cancer cells with PSMA inhibitor-guided gold nanoparticles. Bioorg. Med. Chem. Lett. 2013; 23:565-568. [PubMed: 23232055]

43. El-Sayed IH, Huang X, El-Sayed MA. Selective laser photothermal therapy of epithelial carcinoma using anti-EGFR antibody conjugated gold nanoparticles. Cancer Lett. 2006; 239:129-35. [PubMed: 16198049]

44. Farokhzad OC, Cheng J, Teply BA, Sherifi I, Jon S, Kantoff PW, Richie JP, Langer R. Targeted nanoparticle-aptamer bioconjugates for cancer chemotherapy in vivo. Proc. Natl. Acad. Sci. USA. 2006; 103:6315-6320. [PubMed: 16606824]

45. Yu C, Hu Y, Duan J, Yuan W, Wang C, Xu H, Yang XD. Novel aptamer-nanoparticle bioconjugates enhances delivery of anticancer drug to MUC1-positive cancer cells in vitro. PLoS One. 2011; 6:e24077. [PubMed: 21912664]

46. Singh R, Erickson HK. Antibody-cytotoxic agent conjugates: preparation and characterization. Methods Mol. Biol. 2009; 525:445-467. xiv. [PubMed: 19252846]

47. Jokerst JV, Lobovkina T, Zare RN, Gambhir SS. Nanoparticle PEGylation for imaging and therapy. Nanomedicine (Lond.). 2011; 6:715-728. [PubMed: 21718180]

48. Romberg B, Hennink WE, Storm G. Sheddable coatings for long-circulating nanoparticles. Pharm. Res. 2008; 25:55-71. [PubMed: 17551809]

49. Schipper ML, Iyer G, Koh AL, Cheng Z, Ebenstein Y, Aharoni A, Keren S, Bentolila LA, Li J, Rao J, Chen X, Banin U, Wu AM, Sinclair R, Weiss S, Gambhir SS. Particle size, surface coating, and PEGylation influence the biodistribution of quantum dots in living mice. Small. 2009; 5:126134. [PubMed: 19051182]

50. Shah NB, Vercellotti GM, White JG, Fegan A, Wagner CR, Bischof JC. Blood-nanoparticle interactions and in vivo biodistribution: impact of surface PEG and ligand properties. Mol. Pharm. 2012; 9:2146-2155. [PubMed: 22668197]

51. Xiao K, Li Y, Luo J, Lee JS, Xiao W, Gonik AM, Agarwal RG, Lam KS. The effect of surface charge on in vivo biodistribution of PEG-oligocholic acid based micellar nanoparticles. Biomaterials. 2011; 32:3435-3446. [PubMed: 21295849]

52. Amoozgar Z, Park J, Lin Q, Yeo Y. Low molecular-weight chitosan as a pH-sensitive stealth coating for tumor-specific drug delivery. Mol. Pharm. 2012; 9:1262-1270. [PubMed: 22489704]

53. Minchin RF, Martin DJ. Nanoparticles for molecular imaging - an overview. Endocrinology. 2010; 151:474-481. [PubMed: 20016027]

54. Islam T, Harisinghani MG. Overview of nanoparticle use in cancer imaging. Cancer Biomark. 2009; 5:61-67. [PubMed: 19414922]

55. Will O, Purkayastha S, Chan C, Athanasiou T, Darzi AW, Gedroyc W, Tekkis PP. Diagnostic precision of nanoparticle-enhanced MRI for lymph-node metastases: a meta-analysis. Lancet Oncol. 2006; 7:52-60. [PubMed: 16389184]

56. Peng XH, Qian X, Mao H, Wang AY, Chen ZG, Nie S, Shin DM. Targeted magnetic iron oxide nanoparticles for tumor imaging and therapy. Int. J. Nanomed. 2008; 3:311-321.

57. Yang L, Peng XH, Wang YA, Wang X, Cao Z, Ni C, Karna P, Zhang X, Wood WC, Gao X, Nie S, Mao H. Receptor-targeted nanoparticles for in vivo imaging of breast cancer. Clin. Cancer Res. 2009; 15:4722-4732. [PubMed: 19584158]

58. Hadjipanayis CG, Machaidze R, Kaluzova M, Wang L, Schuette AJ, Chen H, Wu X, Mao H. EGFRvIII antibody-conjugated iron oxide nanoparticles for magnetic resonance imaging-guided convection-enhanced delivery and targeted therapy of glioblastoma. Cancer Res. 2010; 70:63036312. [PubMed: 20647323]

59. Xie J, Liu G, Eden HS, Ai H, Chen X. Surface-engineered magnetic nanoparticle platforms for cancer imaging and therapy. Acc. Chem. Res. 2011; 44:883-892. [PubMed: 21548618]

60. Perrault SD, Chan WC. In vivo assembly of nanoparticle components to improve targeted cancer imaging. Proc. Natl. Acad. Sci. USA. 2010; 107:11194-11199. [PubMed: 20534561]

61. Bogdanov A Jr, Mazzanti ML. Molecular magnetic resonance contrast agents for the detection of cancer: past and present. Semin. Oncol. 2011; 38:42-54. [PubMed: 21362515] 
62. Bogdanov A Jr, Matuszewski L, Bremer C, Petrovsky A, Weissleder R. Oligomerization of paramagnetic substrates result in signal amplification and can be used for MR imaging of molecular targets. Mol. Imaging. 2002; 1:16-23. [PubMed: 12920857]

63. Hainfeld JF, Slatkin DN, Focella TM, Smilowitz HM. Gold nanoparticles: a new X-ray contrast agent. Br. J. Radiol. 2006; 79:248-253. [PubMed: 16498039]

64. Chithrani DB, Dunne M, Stewart J, Allen C, Jaffray DA. Cellular uptake and transport of gold nanoparticles incorporated in a liposomal carrier. Nanomedicine. 2010; 6:161-169. [PubMed: 19447206]

65. Chithrani DB, Jelveh S, Jalali F, van Prooijen M, Allen C, Bristow RG, Hill RP, Jaffray DA. Gold nanoparticles as radiation sensitizers in cancer therapy. Radiat. Res. 2010; 173:719-728. [PubMed: 20518651]

66. Ahmed N, Fessi H, Elaissari A. Theranostic applications of nanoparticles in cancer. Drug Discov. Today. 2012; 17:928-934. [PubMed: 22484464]

67. Smith L, Kuncic Z, Ostrikov K, Kumar S. Nanoparticles in cancer imaging and therapy. J. Nanomater. 2012; 2012:1-7.

68. Yoo D, Lee JH, Shin TH, Cheon J. Theranostic magnetic nanoparticles. Acc. Chem. Res. 2011; 44:863-874. [PubMed: 21823593]

69. Xie J, Lee S, Chen X. Nanoparticle-based theranostic agents. Adv. Drug Deliv. Rev. 2010; 62:1064-1079. [PubMed: 20691229]

70. Kohler N, Sun C, Wang J, Zhang M. Methotrexate-modified superparamagnetic nanoparticles and their intracellular uptake into human cancer cells. Langmuir. 2005; 21:8858-8864. [PubMed: 16142971]

71. Hwu JR, Lin YS, Josephrajan T, Hsu MH, Cheng FY, Yeh CS, Su WC, Shieh DB. Targeted paclitaxel by conjugation to iron oxide and gold nanoparticles. J. Am. Chem. Soc. 2009; 131:6668. [PubMed: 19072111]

72. Yu MK, Jeong YY, Park J, Park S, Kim JW, Min JJ, Kim K, Jon S. Drug-loaded superparamagnetic iron oxide nanoparticles for combined cancer imaging and therapy in vivo. Angew. Chem. Int. Ed. Engl. 2008; 47:5362-5365. [PubMed: 18551493]

73. Manzoor AA, Lindner LH, Landon CD, Park JY, Simnick AJ, Dreher MR, Das S, Hanna G, Park W, Chilkoti A, Koning GA, ten Hagen TL, Needham D, Dewhirst MW. Overcoming limitations in nanoparticle drug delivery: triggered, intravascular release to improve drug penetration into tumors. Cancer Res. 2012; 72:5566-5575. [PubMed: 22952218]

74. Ghosh S, Dutta S, Gomes E, Carroll D, D’Agostino R Jr, Olson J, Guthold M, Gmeiner WH. Increased heating efficiency and selective thermal ablation of malignant tissue with DNA-encased multiwalled carbon nanotubes. ACS Nano. 2009; 3:2667-2673. [PubMed: 19655728]

75. Love SA, Maurer-Jones MA, Thompson JW, Lin YS, Haynes CL. Assessing nanoparticle toxicity. Annu. Rev. Anal. Chem. (Palo Alto Calif.). 2012; 5:181-205. [PubMed: 22524221]

76. Elias DR, Poloukhtine A, Popik V, Tsourkas A. Effect of ligand density, receptor density, and nanoparticle size on cell targeting. Nanomedicine. 2013; 9:194-201. [PubMed: 22687896]

77. Maeda H, Nakamura H, Fang J. The EPR effect for macromolecular drug delivery to solid tumors: improvement of tumor uptake, lowering of systemic toxicity, and distinct tumor imaging in vivo. Adv. Drug Deliv. Rev. 2013; 65:71-79. [PubMed: 23088862]

78. Liu C, Liu F, Feng L, Li M, Zhang J, Zhang N. The targeted co-delivery of DNA and doxorubicin to tumor cells via multifunctional PEI-PEG based nanoparticles. Biomaterials. 2013; 34:25472564. [PubMed: 23332321]

79. Stern ST, McNeil SE. Nanotechnology safety concerns revisited. Toxicol. Sci. 2008; 101:4-21. [PubMed: 17602205]

80. Stinchcombe TE. Nanoparticle albumin-bound paclitaxel: a novel Cremphor-EL-free formulation of paclitaxel. Nanomedicine (Lond.). 2007; 2:415-423. [PubMed: 17716129]

81. Zhang C, Awasthi N, Schwarz MA, Hinz S, Schwarz RE. Superior antitumor activity of nanoparticle albumin-bound paclitaxel in experimental gastric cancer. PLoS One. 2013; 8:e58037. [PubMed: 23460921] 
82. Pardee TS, Gomes E, Jennings-Gee J, Caudell D, Gmeiner WH. Unique dual targeting of thymidylate synthase and topoisomerase 1 by FdUMP[10] results in high efficacy against AML and low toxicity. Blood. 2012; 119:3561-3570. [PubMed: 22362039]

83. Brewer S, Nair-Gill E, Wei B, Chen L, Li X, Riedinger M, Campbell DO, Wiltzius S, Satyamurthy N, Phelps ME, Radu C, Witte ON, Braun J. Epithelial uptake of [18F]1-(2'-deoxy-2'arabinofuranosyl) cytosine indicates intestinal inflammation in mice. Gastroenterology. 2010; 138:1266-1275. [PubMed: 20080095]

84. Schwarzenberg J, Radu CG, Benz M, Fueger B, Tran AQ, Phelps ME, Witte ON, Satyamurthy N, Czernin J, Schiepers C. Human biodistribution and radiation dosimetry of novel PET probes targeting the deoxyribonucleoside salvage pathway. Eur. J. Nucl. Med. Mol. Imaging. 2011; 38:711-721. [PubMed: 21127859]

85. Boles KS, Schmieder AH, Koch AW, Carano RA, Wu Y, Caruthers SD, Tong RK, Stawicki S, Hu G, Scott MJ, Zhang H, Reynolds BA, Wickline SA, Lanza GM. MR angiogenesis imaging with Robo4-vs. alphaVbeta3-targeted nanoparticles in a B16/F10 mouse melanoma model. FASEB J. 2010; 24:4262-4270. [PubMed: 20585027]

86. Winter PM, Caruthers SD, Kassner A, Harris TD, Chinen LK, Allen JS, Lacy EK, Zhang H, Robertson JD, Wickline SA, Lanza GM. Molecular imaging of angiogenesis in nascent Vx-2 rabbit tumors using a novel alpha(nu)beta3-targeted nanoparticle and 1.5 tesla magnetic resonance imaging. Cancer Res. 2003; 63:5838-5843. [PubMed: 14522907]

87. Castro JE, Melo-Cardenas J, Urquiza M, Barajas-Gamboa JS, Pakbaz RS, Kipps TJ. Gene immunotherapy of chronic lymphocytic leukemia: a phase I study of intranodally injected adenovirus expressing a chimeric CD154 molecule. Cancer Res. 2012; 72:2937-2948. [PubMed: 22505652]

88. Bartlett DW, Davis ME. Impact of tumor-specific targeting and dosing schedule on tumor growth inhibition after intravenous administration of siRNA-containing nanoparticles. Biotechnol. Bioeng. 2008; 99:975-985. [PubMed: 17929316]

89. Davis ME, Zuckerman JE, Choi CH, Seligson D, Tolcher A, Alabi CA, Yen Y, Heidel JD, Ribas A. Evidence of RNAi in humans from systemically administered siRNA via targeted nanoparticles. Nature. 2010; 464:1067-1070. [PubMed: 20305636]

90. Heidel JD, Yu Z, Liu JY, Rele SM, Liang Y, Zeidan RK, Kornbrust DJ, Davis ME. Administration in non-human primates of escalating intravenous doses of targeted nanoparticles containing ribonucleotide reductase subunit M2 siRNA. Proc. Natl. Acad. Sci. USA. 2007; 104:5715-5721. [PubMed: 17379663]

91. Schluep T, Hwang J, Cheng J, Heidel JD, Bartlett DW, Hollister B, Davis ME. Preclinical efficacy of the camptothecin-polymer conjugate IT-101 in multiple cancer models. Clin. Cancer Res. 2006; 12:1606-1614. [PubMed: 16533788]

92. Ghazani, AA.; McDermott, S.; Pectasides, M.; Sebas, M.; Mino-Kenudson, M.; Lee, H.; Weissleder, R.; Castro, CM. Comparison of select cancer biomarkers in human circulating and bulk tumor cells using magnetic nanoparticles and a miniaturized micro-NMR system. Nanomedicine. NBM 2013;xx:1-9, http://dx.doi.org/10.1016/j.nano.2013.03.011

93. Niibe Y, Hayakawa K. Oligometastases and oligo-recurrence: the new era of cancer therapy. Jpn. J. Clin. Oncol. 2010; 40:107-111. [PubMed: 20047860]

94. Veltri A, Guarnieri T, Gazzera C, Busso M, Solitro F, Fora G, Racca P. Long-term outcome of radiofrequency thermal ablation (RFA) of liver metastases from colorectal cancer (CRC): size as the leading prognostic factor for survival. Radiol. Med. 2012; 117:1139-1151. [PubMed: 22430677]

95. Mylona S, Stroumpouli E, Pomoni M, Galani P, Ntai S, Thanos L. Radiofrequency ablation of liver metastases from cancer of unknown primary site. Diagn. Interv. Radiol. 2009; 15:297-302. [PubMed: 19908183]

96. Vogl TJ, Naguib NN, Nour-Eldin NE, Mack MG, Zangos S, Abskharon JE, Jost A. Repeated chemoembolization followed by laser-induced thermotherapy for liver metastasis of breast cancer. AJR Am. J. Roentgenol. 2011; 196:W66-W72. [PubMed: 21178035]

97. Vogl TJ, Naguib NN, Gruber-Rouh T, Koitka K, Lehnert T, Nour-Eldin NE. Microwave ablation therapy: clinical utility in treatment of pulmonary metastases. Radiology. 2011; 261:643-651. [PubMed: 22012906] 
98. Lo SS, Moffatt-Bruce SD, Dawson LA, Schwarz RE, Teh BS, Mayr NA, Lu JJ, Grecula JC, Olencki TE, Timmerman RD. The role of local therapy in the management of lung and liver oligometastases. Nat. Rev. Clin. Oncol. 2011; 8:405-416. [PubMed: 21606970]

99. Zheng Y, Fernando HC. Surgical and nonresectional therapies for pulmonary metastasis. Surg. Clin. North Am. 2010; 90:1041-1051. [PubMed: 20955882]

100. Mayo SC, Pawlik TM. Thermal ablative therapies for secondary hepatic malignancies. Cancer J. 2010; 16:111-117. [PubMed: 20404607]

101. Cornelis F, Balageas P, Le Bras Y, Rigou G, Boutault JR, Bouzgarrou M, Grenier N. Radiologically-guided thermal ablation of renal tumours. Diagn. Interv. Imaging. 2012; 93:246261. [PubMed: 22464994]

102. Lorentzen T, Skjoldbye BO, Nolsoe CP. Microwave ablation of liver metastases guided by contrast-enhanced ultrasound: experience with 125 metastases in 39 patients. Ultraschall Med. 2011; 32:492-496. [PubMed: 21259183]

103. Vogl TJ, Farshid P, Naguib NN, Zangos S. Thermal ablation therapies in patients with breast cancer liver metastases: a review. Eur. Radiol. 2013; 23:797-804. [PubMed: 23064713]

104. Munireddy S, Katz S, Somasundar P, Espat NJ. Thermal tumor ablation therapy for colorectal cancer hepatic metastasis. J. Gastrointest. Oncol. 2012; 3:69-77. [PubMed: 22811871]

105. Mues AC, Mucksavage P, Graversen JA, Landman J. BioGlue surgical adhesive as a thermal reflector during laparoscopic cryoablation: effect on iceball size and ablation zone diameter. JSLS. 2012; 16:23-26. [PubMed: 22906325]

106. Kawaguchi M, Ohno J, Irie A, Fukushima T, Yamazaki J, Nakashima N. Dispersion stability and exothermic properties of DNA-functionalized single-walled carbon nanotubes. Int. J. Nanomed. 2011; 6:729-736.

107. Kawaguchi M, Yamazaki J, Ohno J, Fukushima T. Preparation and binding study of a complex made of DNA-treated single-walled carbon nanotubes and antibody for specific delivery of a "molecular heater" platform. Int. J. Nanomed. 2012; 7:4363-4371.

108. Bozzini G, Colin P, Nevoux P, Villers A, Mordon S, Betrouni N. Focal therapy of prostate cancer: energies and procedures. Urol. Oncol. 2013; 31:155-167. [PubMed: 22795500]

109. Haen SP, Pereira PL, Salih HR, Rammensee HG, Gouttefangeas C. More than just tumor destruction: immunomodulation by thermal ablation of cancer. Clin. Dev. Immunol. 2011; 2011:160250. [PubMed: 22242035]

110. Bader MJ, Stepp H, Beyer W, Pongratz T, Sroka R, Kriegmair M, Zaak D, Welschof M, Tilki D, Stief CG, Waidelich R. Photodynamic therapy of bladder cancer - a phase I Study Using Hexaminolevulinate (HAL). Urol Oncol. 2012

111. Lindenmann J, Matzi V, Neuboeck N, Anegg U, Baumgartner E, Maier A, Smolle J, SmolleJuettner FM. Individualized, multimodal palliative treatment of inoperable esophageal cancer: clinical impact of photodynamic therapy resulting in prolonged survival. Lasers Surg. Med. 2012; 44:189-198. [PubMed: 22334351]

112. Sawa M, Iwata E, Ishikawa K, Gomi F, Nishida K, Terasaki H. Comparison of different treatment intervals between bevacizumab injection and photodynamic therapy in combined therapy for agerelated macular degeneration. Jpn. J. Ophthalmol. 2012; 56:470-475. [PubMed: 22678809]

113. Ethirajan M, Chen Y, Joshi P, Pandey RK. The role of porphyrin chemistry in tumor imaging and photodynamic therapy. Chem. Soc. Rev. 2010; 40:340-362. [PubMed: 20694259]

114. Chin WW, Heng PW, Thong PS, Bhuvaneswari R, Hirt W, Kuenzel S, Soo KC, Olivo M. Improved formulation of photosensitizer chlorin e6 polyvinylpyrrolidone for fluorescence diagnostic imaging and photodynamic therapy of human cancer. Eur. J. Pharm. Biopharm. 2008; 69:1083-1093. [PubMed: 18396019]

115. Rosi NL, Giljohann DA, Thaxton CS, Lytton-Jean AK, Han MS, Mirkin CA. Oligonucleotidemodified gold nanoparticles for intracellular gene regulation. Science. 2006; 312:1027-1030. [PubMed: 16709779]

116. Wang Z, Liu H, Yang SH, Wang T, Liu C, Cao YC. Nanoparticle-based artificial RNA silencing machinery for antiviral therapy. Proc. Natl. Acad. Sci. USA. 2012; 109:12387-12392. [PubMed: 22802676] 
117. Fabbro C, Ali-Boucetta H, Da Ros T, Kostarelos K, Bianco A, Prato M. Targeting carbon nanotubes against cancer. Chem. Commun. (Camb.). 2012; 48:3911-3926. [PubMed: 22428156]

118. Gerweck LE. Modification of cell lethality at elevated temperatures. The pH effect. Radiat. Res. 1977; 70:224-235.

119. Dewey, WF.; Freeman, ML.; Raaphorst, GP. Cellular biology of hyperthermia and radiation. In: Meyn Raymond, E.; Withers, H. Rodney, editors. Radiation Biology in Cancer Research. 32nd. New York: Raven Press; 1980. Series: M. D. Anderson Symposia on Fundamental Cancer Research

120. Szlachcic A, Pala K, Zakrzewska M, Jakimowicz P, Wiedlocha A, Otlewski J. FGF1-gold nanoparticle conjugates targeting FGFR efficiently decrease cell viability upon NIR irradiation. Int. J. Nanomed. 2012; 7:5915-5927.

121. You J, Zhang R, Xiong C, Zhong M, Melancon M, Gupta S, Nick AM, Sood AK, Li C. Effective photothermal chemotherapy using doxorubicin-loaded gold nanospheres that target EphB4 receptors in tumors. Cancer Res. 2012; 72:4777-4786. [PubMed: 22865457]

122. Silva AC, Oliveira TR, Mamani JB, Malheiros SM, Malavolta L, Pavon LF, Sibov TT, Amaro E Jr, Tannus A, Vidoto EL, Martins MJ, Santos RS, Gamarra LF. Application of hyperthermia induced by superparamagnetic iron oxide nanoparticles in glioma treatment. Int. J. Nanomed. 2011; 6:591-603.

123. Grull H, Langereis S. Hyperthermia-triggered drug delivery from temperature-sensitive liposomes using MRI-guided high intensity focused ultrasound. J. Control. Release. 2012; 161:317-327. [PubMed: 22565055]

124. Krishnan KM. Biomedical nanomagnetics: a spin through possibilities in imaging, diagnostics, and therapy. IEEE Trans. Magn. 2010; 46:2523-2558. [PubMed: 20930943]

125. Buzea C, Pacheco II, Robbie K. Nanomaterials and nanoparticles: sources and toxicity. Biointerphases. 2007; 2:MR17-MR71. [PubMed: 20419892]

126. Zern BJ, Chacko AM, Liu J, Greineder CF, Blankemeyer ER, Radhakrishnan R, Muzykantov V. Reduction of nanoparticle avidity enhances the selectivity of vascular targeting and PET detection of pulmonary inflammation. ACS Nano. 2013; 7:2461-2469. [PubMed: 23383962]

127. Kettering M, Winter J, Zeisberger M, Alexiou C, Bremer-Streck S, Bergemann C, Kaiser WA, Hilger I. Magnetically based enhancement of nanoparticle uptake in tumor cells: combination of magnetically induced cell labeling and magnetic heating. Rofo. 2006; 178:1255-1260. [PubMed: 17136650]

128. Huang XL, Zhang B, Ren L, Ye SF, Sun LP, Zhang QQ, Tan MC, Chow GM. In vivo toxic studies and biodistribution of near infrared sensitive $\mathrm{Au}-\mathrm{Au}(2) \mathrm{S}$ nanoparticles as potential drug delivery carriers. J. Mater. Sci. Mater. Med. 2008; 19:2581-2588. [PubMed: 17665103]

129. Kim J, Piao Y, Hyeon T. Multifunctional nanostructured materials for multimodal imaging, and simultaneous imaging and therapy. Chem. Soc. Rev. 2009; 38:372-390. [PubMed: 19169455]

\section{Biography}

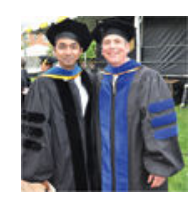

Supratim Ghosh (left) received BSc and MSc degrees from the University of Calcutta and recently received his PhD from the Molecular Genetics program at WFSM performing research focused on improved cancer treatment using nanotechnology under the supervision of Dr. Gmeiner.

William Gmeiner (right) was awarded a Bachelor's degree with honors from the University of Chicago and a PhD in Chemistry from the University of Utah and was an Alberta 
Heritage Medical Research Fellow. Dr. Gmeiner is currently Professor of Cancer Biology at Wake Forest School of Medicine. He has published more than 70 peer-reviewed articles in chemistry, cancer biology, and nanomedicine and recently was granted a SPARK award for innovative new research at WFSM. 


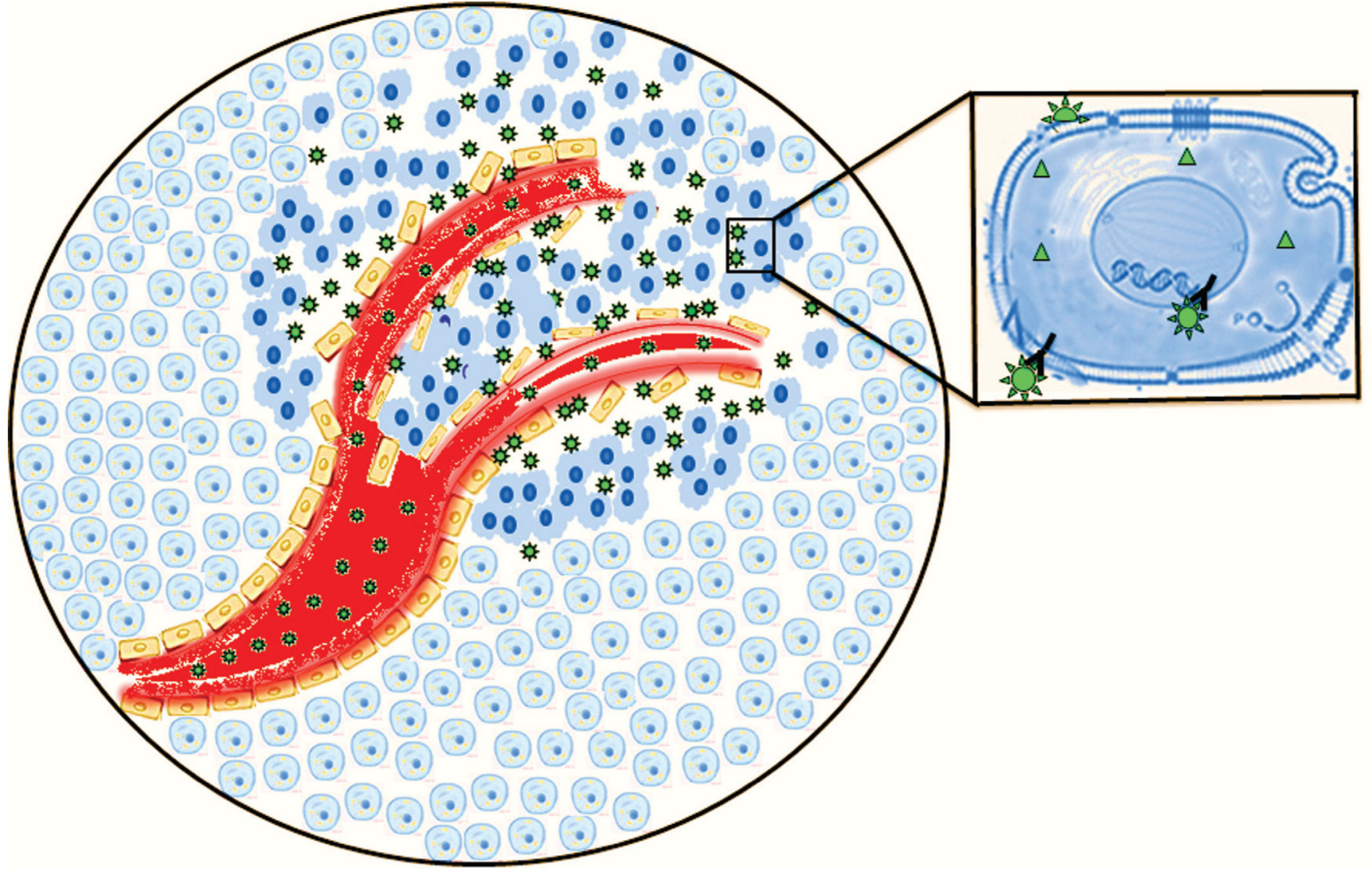

Figure 1.

Depiction of NP targeting of malignant cells through both active and passive targeting. NPs (green stars) accumulate in tumor tissue via the EPR - a form of passive targeting. Inset shape-specific interaction of the NPs with cell-surface receptors is indicated by "Y-star" interactions that represent active targeting of NPs to cancer cells based upon specific molecular interactions. 


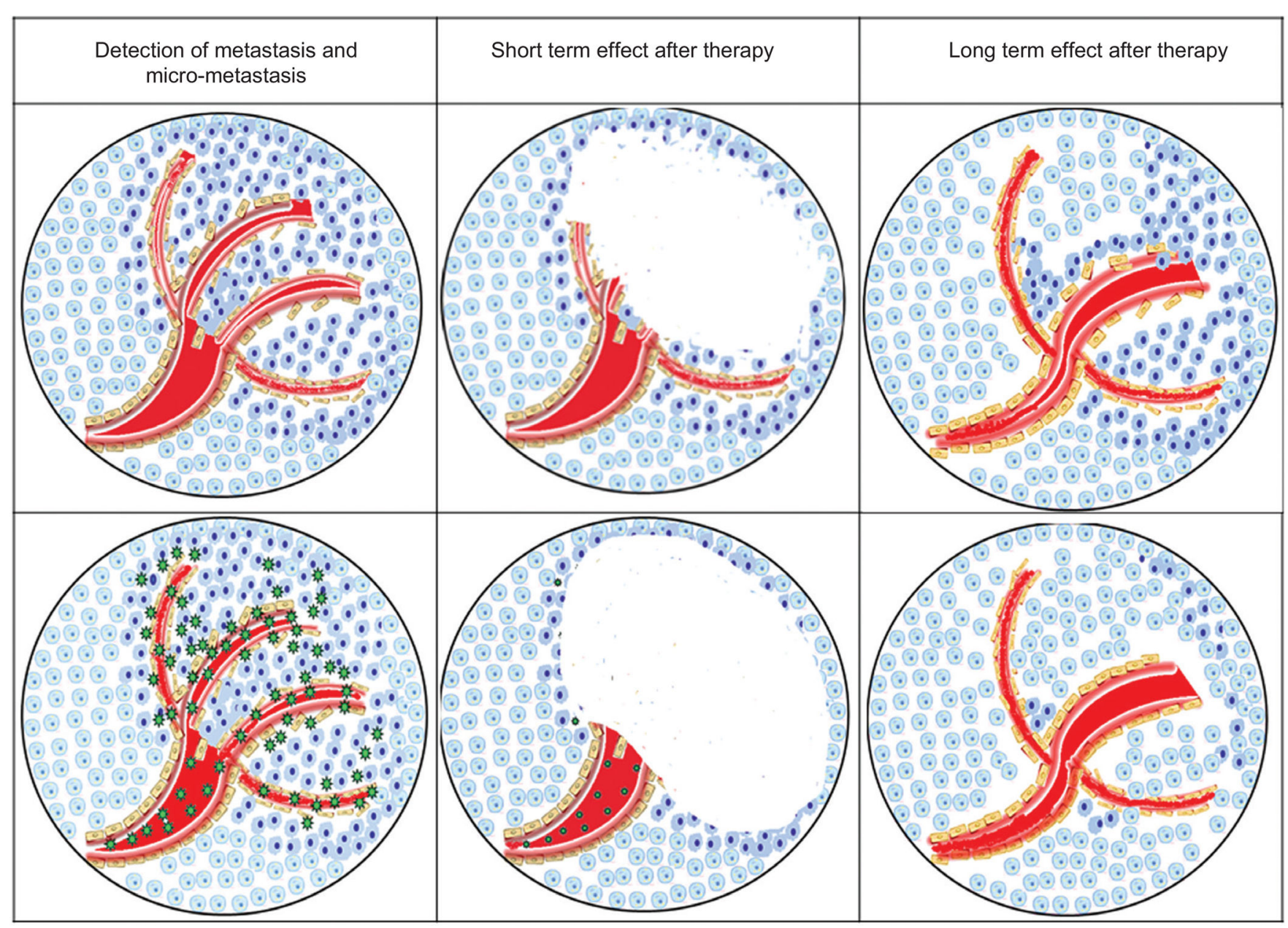

Figure 2.

Comparison of short- and long-term effects of treatment with conventional agents (top panels) and NPs that use both active and passive targeting of malignant cells (bottom panels). Conventional approaches are equally effective in the short term; however, micrometastases remain and repopulate the tumor in the long term. Targeted NPs destroy micrometastases resulting in long-term therapeutic benefit. 